\title{
Environmental Toxicity Analysis and Reduction of Ceramsite Synthesis from Industrial Coal Gasification Coarse Cinder Waste
}

\author{
Jianli Jia ${ }^{1 *}$, Lei Hu${ }^{1}$, Jiaxing Zheng ${ }^{1}$, Yujia Zhai ${ }^{2}$, Peng Yao ${ }^{3}$, \\ Shenwei Zhao ${ }^{1}$, Shaohe Shi ${ }^{1}$, Xiaobo Zhai ${ }^{1}$, Dayi Zhang ${ }^{4}$ \\ ${ }^{1}$ School of Chemical and Environmental Engineering, China University of Mining and Technology (Beijing), \\ Beijing 100083, PR China \\ ${ }^{2}$ Research Institute, Shanghai Municipal Engineering Design Institute (Group) CO., LTD, \\ Shanghai 200092, PR China \\ ${ }^{3}$ Chinese Research Academy of Environmental Sciences, Beijing 100012, PR China \\ ${ }^{4}$ Lancaster Environment Centre, Lancaster University, \\ Lancaster LA1 4YQ, UK
}

Received: 2 June 2016

Accepted: 15 August 2016

\begin{abstract}
Coal gasification coarse cinder (CGCC) is the main waste in the coal gasification industry, containing low calorific value but high heavy metal residuals. To achieve environmental toxicity stabilization and waste recycling, we developed a manufacturing method of multiple-functional ceramsite from CGCC by pelletizing and sintering. By altering key parameters during the manufacturing process (including CGCC content, sintering temperature, and time), the physical properties and leaching toxicity of ceramsite were evaluated. Sintering temperature was identified with a significantly positive relationship with ceramsite's compressive strength, whereas CGCC content was negatively correlated with water adsorption. The highest compressive strength $(24.00 \mathrm{MPa})$ and relatively lower water absorption $(21.36 \%)$ was achieved at $50 \%$ CGCC content and $1,150^{\circ} \mathrm{C}$ sintering for $30 \mathrm{~min}$. The toxicity tests showed acceptable leaching heavy metals with minimal environmental impact. Considering the energy conservation and the maximal recycling of CGCC, optimal ceramsite manufacturing is suggested as $50 \%$ CGCC content and $1,150^{\circ} \mathrm{C} / 10$ min sintering temperature/time. Our results indicated that multiple-functional ceramsite manufacturing is a low-cost and environmentally friendly approach for CGCC recycling.
\end{abstract}

Keywords: ceramsite, coal gasification coarse cinder (CGCC), heavy metals, compressive strength, environmental toxicity

*e-mail: jj1@cumtb.edu.cn 


\section{Introduction}

Coal gasification coarse cinder (CGCC) is a byproduct during the industrial coal process [1]. Landfill is the traditional CGCC disposal method [2-3], which was not environmental friendly due to the release of heavy metals and polycyclic aromatic hydrocarbons (PAHs) into soils and groundwater [3-4]. Long-term contamination consequently decreases soil quality and threatens human health [5-6]. Thus, to explore a safe and feasible way for recycling CGCC is an urgent need. Recycling for CGCC could achieve the possibility of using this waste which contained heavy metals as a safe resource, avoiding the consumption of raw materials and making a great contribution to the development of the local economy [7]. Many studies therefore addressed alternative approaches for comprehensive utilization of CGCC to reduce the potential environmental risk and recycle it as valuable functional materials.

A previous study on the recycling of coal-based solid wastes predominantly addressed the high calorific and fine particulate matters, such as coal fly ash, lime mud, and wastewater treatment sludge. Qin et al. successfully manufactured ceramsite from lime mud and coal fly ash as a new high-performance product through waste recycling [8]. Via sintering and alkaline hydrothermal reaction, construction and demolition wastes were transferred into zeolite-loaded ceramsite [9]. The green ceramsite from sewage sludge also showed the potential of recycling wastes as the light weight aggregates in industrial practices [10]. However, though CGCC has high yield at the coal processing cites, there were few studies for its reutilization due to such difficulties as low calorific value, large particle size, and high heavy metal concentrations. Given the fact that $\mathrm{CGCC}$ has the main components as $\mathrm{SiO}_{2}, \mathrm{CaO}, \mathrm{Fe}_{2} \mathrm{O}_{3}$, and $\mathrm{Al}_{2} \mathrm{O}_{3}$, it is hypothesized as appropriate raw material for ceramsite manufacturing [8], but its leaching toxicity needs particular attention for environmental risk control and management.

In this study, we developed a manufacturing method of multiple-functional ceramsite from CGCC by pelletizing and sintering. Both physical properties and environmental leaching toxicity of the ceramsite were evaluated and linked to manufacturing parameters as raw material ratio, sintering temperature, and sintering time. The manufacturing conditions were therefore optimized as effective CGCC recycling approach for high-quality ceramsite with minimal toxic risks.

Table 1. Raw material contents for ceramsite manufacturing.

\begin{tabular}{|c|c|c|c|}
\hline Group & CGCC (\%) & Clay (\%) & Quartz sand (\%) \\
\hline 1 & 20 & 40 & 40 \\
\hline 2 & 35 & 25 & 40 \\
\hline 3 & 50 & 25 & 25 \\
\hline 4 & 65 & 10 & 25 \\
\hline
\end{tabular}

This paper is organized as follows: after the introduction is presented in the first section, the second section covers the materials of manufacturing ceramsite and methods for chemical and morphological analysis, physical analysis, and data analysis. The third section contains the results, discussion, and comparisons with national standards. The conclusions and recommendations for decision makers are presented in the final section.

\section{Materials and Methods}

\section{Manufacturing Ceramsite from Coal Gasification Coarse Cinder}

The CGCC and coal fly ash were collected from the methanol plant of Yulin Energy and Chemical Industry, Yanzhou Coal Corporation, China (N38³4'41.9', E109 $55^{\prime} 50.4$ "). After being dried at $105^{\circ} \mathrm{C}$ for two hours, smashed by a grinder for three minutes, and sieved by 60 mesh sieve, the CGCC was then mixed with clay/quartz (the CGCC content listed in Table 1) and sintered in a silicon molybdenum furnace. Sixteen treatments were carried out to optimize the physical properties of ceramsite, including sintering temperature from $1,000^{\circ} \mathrm{C}$ to $1,150^{\circ} \mathrm{C}$, sintering time from $10 \mathrm{~min}$ to 90 minutes, and CGCC content from $20 \%$ to $65 \%$ (Table 2). The raw meal ball could not form a meal ball structure when CGCC content was $65 \%$, so No. $1-12$ treatments were available.

Table 2. Orthogonal treatments.

\begin{tabular}{|c|c|c|c|}
\hline Treatments & $\begin{array}{c}\text { CGCC } \\
\text { content }(\%)\end{array}$ & $\begin{array}{c}\text { Temperature } \\
\left({ }^{\circ} \mathrm{C}\right)\end{array}$ & Time (min) \\
\hline 1 & 20 & 1,000 & 10 \\
\hline 2 & 20 & 1,050 & 30 \\
\hline 3 & 20 & 1,100 & 60 \\
\hline 4 & 20 & 1,150 & 90 \\
\hline 5 & 35 & 1,000 & 30 \\
\hline 6 & 35 & 1,050 & 60 \\
\hline 7 & 35 & 1,100 & 90 \\
\hline 8 & 35 & 1,150 & 10 \\
\hline 9 & 50 & 1,000 & 60 \\
\hline 10 & 50 & 1,050 & 90 \\
\hline 11 & 50 & 1,100 & 10 \\
\hline 12 & 50 & 1,150 & 30 \\
\hline 13 & 65 & 1,000 & 90 \\
\hline 14 & 65 & 1,050 & 10 \\
\hline 15 & 65 & 1,100 & 30 \\
\hline 16 & 65 & 1,150 & 60 \\
\hline & & & \\
\hline & 55 & 200 & 60 \\
\hline
\end{tabular}


Table 3. The main components in CGCC.

\begin{tabular}{|c|c|c|c|c|c|c|c|}
\hline Components & $\mathrm{SiO}_{2}$ & $\mathrm{Al}_{2} \mathrm{O}_{3}$ & $\mathrm{CaO}$ & $\mathrm{Fe}_{2} \mathrm{O}_{3}$ & $\mathrm{Na}_{2} \mathrm{O}$ & $\mathrm{MgO}$ & $\mathrm{C}$ \\
\hline Contents (\%) & 20.12 & 8.23 & 30.08 & 18.17 & 2.14 & 1.93 & 16.12 \\
\hline
\end{tabular}

\section{Chemical and Morphological Analysis}

The key components in CGCC were analyzed by x-ray fluorescence spectroscopy (XRF, ARLADVANT XP+, Thermo, USA). The key components are listed in Table 3 . The leaching trace elements $(\mathrm{Cr}, \mathrm{As}$, and $\mathrm{Hg}$ ) were detected by inductively coupled plasma mass spectrometry (ICP-MS, 7500A, Agilent, USA). The morphology was analyzed by a scanning electron microscope (SEM, S-4800, Hitachi, Japan). The surface functional groups of CGCC and ceramsite were characterized by a Fourier transform infrared spectrometer (FTIR, TENSOR II, Bruker, Germany).

\section{Ceramsite Physical Analysis}

The compressive strength of ceramsite was analyzed by pressure tester from 0 to $125 \mathrm{MPa}$ with three individ-

a)

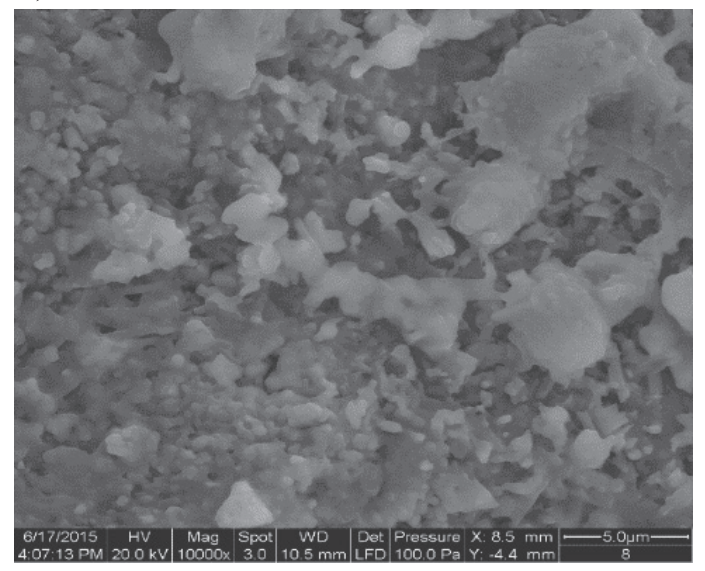

c)

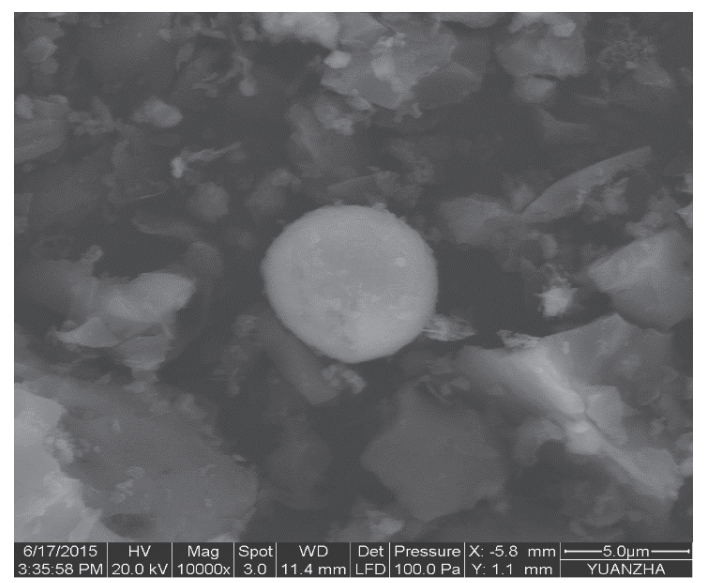

ual replicates. Water absorption was measured by drying the ceramsite to constant weight, soaking for two hours, transferring into the container with water, and finally evacuating for $10 \mathrm{~min}$. Water adsorption was calculated following Equation (1).

$$
W=\frac{G_{1}-G_{0}}{G_{0}} \times 100 \%
$$

...where $\mathrm{W}$ represents water absorption (\%), and $\mathrm{G}_{0}$ and $\mathrm{G}_{1}$ refer to ceramsite weight $(\mathrm{g})$ before immersion in water and after evacuation, respectively.

\section{Data Analysis}

The environmental toxicity analysis of original CGCC and manufactured ceramsite followed the National Solid Waste Method for Leaching Toxicity Industry Standards

b)

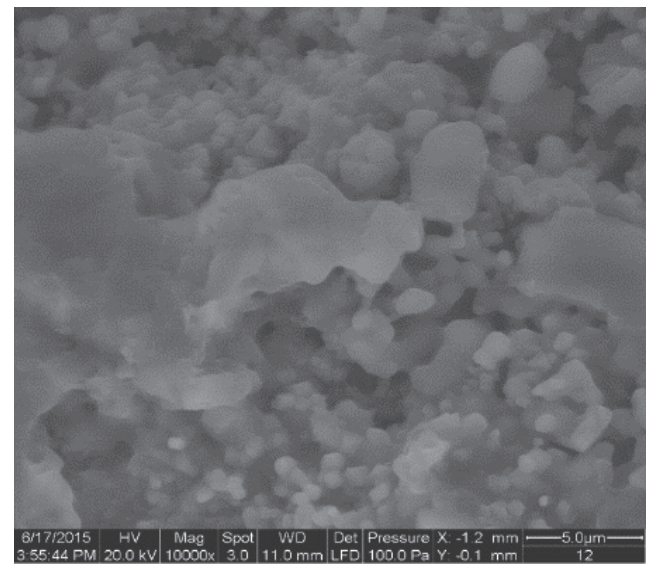

d)

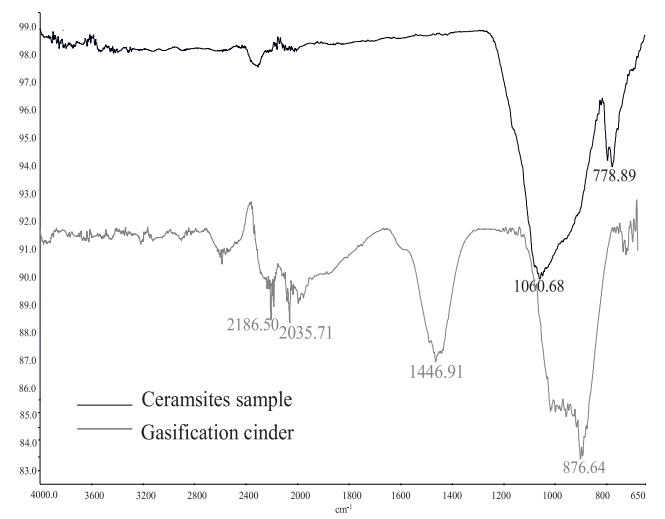

Fig. 1. SEM (10,000× magnification) of original CGCC c) and two ceramsites (a) for $35 \% / 1150^{\circ} \mathrm{C} / 10 \mathrm{~min}$ and b) for $50 \% / 1150^{\circ} \mathrm{C} / 30 \mathrm{~min}$ ). FTIR spectrum of CGCC and ceramsite d). 
a)

Pearson correlation coefficient $=0.743$

$\mathrm{p}$-value $=0.006$

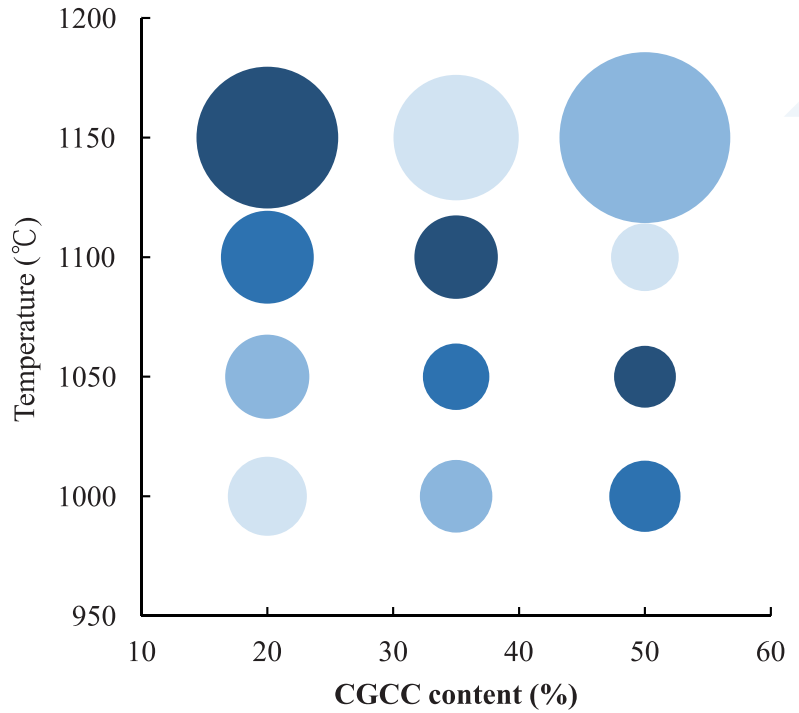

Sintering time (min) $\bullet 10 \bullet 30 \bullet 60 \bullet 90$ b) Pearson correlation coefficient $=0.779$

$\mathrm{p}$-value $=0.003$

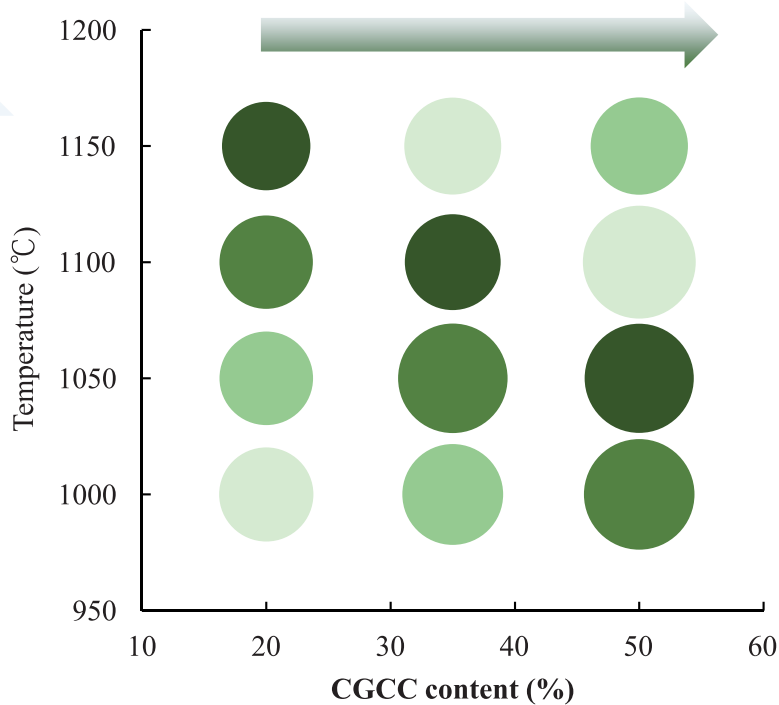

Sintering time (min) $\bullet 10 \quad 30 \bullet 60 \bullet 90$

Fig. 2. Ceramsite compressive strength a) and water absorption b). The diameter of the air bubble is positively correlated with compressive strength or water absorption, and the various shades represent different sintering times.

(HJ/T299-2007). SPSS software (version 17.0.0) was used for statistical analysis.

\section{Results and Discussion}

The surface morphology by SEM illustrated a better crystallization of ceramsite (Figs 1a-b) than raw CGCC (Fig. 1c). Sintered at $1,150^{\circ} \mathrm{C}$, the formation of spherical structure showed the molten reaction between clay CGCC, forming the glass phase and further the stable crystal lattice structure, different from the anorthite in fly ash ceramic $[8,11]$. Thus, the ceramsite morphology change indicated the smooth space structure and the mutual adhesion after sintering with improved compressive strength, instead of the loose and coarse grain structure of raw CGCC. The FTIR spectrum (Fig. 1d) illustrated the existence of $\mathrm{C} \equiv \mathrm{C}$ stretching vibration $\left(2,186.5\right.$ and $\left.2,035.71 \mathrm{~cm}^{-1}\right)$ in

Table 4. The compressive strength and water absorption of ceramsite under different manufacturing conditions.

\begin{tabular}{|c|c|c|c|c|c|}
\hline \multicolumn{3}{|c|}{ Samples } & Compressive strength (MPa) & Water absorption (\%) & Results \\
\hline CGCC content $(\%)$ & Temperature $\left({ }^{\circ} \mathrm{C}\right)$ & Time (min) & $>5$ & $<22$ & - \\
\hline 20 & 1,000 & 10 & 5.14 & 20.03 & Qualified \\
\hline 20 & 1,050 & 30 & 5.83 & 19.82 & Qualified \\
\hline 20 & 1,100 & 60 & 7.09 & 19.70 & Qualified \\
\hline 20 & 1,150 & 90 & 16.55 & 17.66 & Qualified \\
\hline 35 & 1,000 & 30 & 4.34 & 22.96 & Unqualified \\
\hline 35 & 1,050 & 60 & 3.64 & 27.09 & Unqualified \\
\hline 35 & 1,100 & 90 & 5.74 & 20.74 & Qualified \\
\hline 35 & 1,150 & 10 & 12.93 & 21.24 & Qualified \\
\hline 50 & 1,000 & 60 & 4.19 & 27.60 & Unqualified \\
\hline 50 & 1,050 & 90 & 3.15 & 26.94 & Unqualified \\
\hline 50 & 1,100 & 10 & 3.77 & 28.77 & Unqualified \\
\hline 50 & 1,150 & 30 & 24.00 & 21.36 & Qualified \\
\hline
\end{tabular}


Table 5. Properties comparison of CGCC and coal fly ash.

\begin{tabular}{|c|c|c|c|c|c|c|c|c|}
\hline \multirow{2}{*}{ Components } & \multicolumn{5}{|c|}{ Trace elements $(\mathrm{mg} / \mathrm{kg})$} & \multirow{2}{*}{$\begin{array}{c}\text { Total water } \\
(\mathrm{wt} \%)\end{array}$} & $\begin{array}{c}\text { Fixed carbon } \\
(\mathrm{wt} \%)\end{array}$ & $\begin{array}{c}\text { Dry basis calorific value } \\
(\mathrm{kcal} / \mathrm{kg})\end{array}$ \\
\cline { 2 - 9 } & $\mathrm{As}$ & $\mathrm{Cr}$ & $\mathrm{Hg}$ & $\mathrm{Cd}$ & $\mathrm{Cu}$ & 28.94 & 16.12 & 757.0 \\
\hline CGCC & 84.24 & 920.82 & 3.8 & 0.12 & 22.66 & 47.01 & 2465.4 \\
\hline Coal fly ash & 24.51 & 139.88 & 0.001 & 0.80 & 53.73 & 64.65 & 47.01 \\
\hline
\end{tabular}

CGCC, but weakened after sintering. Besides, the peaks of $1,446.91 \mathrm{~cm}^{-1}$ and $8,76.64 \mathrm{~cm}^{-1}$ represented the $-\mathrm{CH}_{3}$ deformation vibration of aliphatic hydrocarbons and outof-plane wag of vinyl compounds, respectively [12]. These characteristic peaks indicated the richness of unsaturated organic compounds in CGCC, and their strength was significantly reduced in ceramsite due to oxidation during the high-temperature sintering. Instead, the formation of $1,060 \mathrm{~cm}^{-1}$ and $778.9 \mathrm{~cm}^{-1}$ in ceramsite, referring to the stretching vibration of Si-O-Si [13] and Al-O [14], were attributed to the inorganic functional groups from clay components.

Ceramsite compressive strength and water absorption are illustrated in Fig. 2 and Table 4. Correlation analysis identified sintering temperature as the key factor affecting compressive strength ( $\mathrm{p}$-value $=0.006$; Fig. 2a). The increasing compressive strength with sintering temperature was explained by the more molten and glassy phase at higher temperatures [8, 15]. Compared to the national standard (GB/T 17431.1-2010) that the qualified ceramsite should achieve compressive strength above $5 \mathrm{MPa}$, the suggested sintering temperature is more than $1,100^{\circ} \mathrm{C}$. The CGCC content (raw material ratio) was positively correlated with water absorption (p-value $=0.003$; Fig. $2 b$ ). The lowest water absorption was obtained $(19.7 \%)$ when the CGCC content was $20 \%$, fitting with the national qualified water absorption standard $(<22 \%, \mathrm{~GB} / \mathrm{T} 17431.1-2010)$. Attributed to the strong water adsorption capacity of CGCC, high CGCC content consequently resulted in more water adsorption and reduced ceramsite quality, which needs particular attention during the sintering process. From principle component analysis, sintering time has limited impact on the physical properties of ceramsite, whereas sintering temperature and CGCC content contributed over $80 \%$.

The heavy metal elements (Cr, As, and Hg) in CGCC are significantly higher than those in coal fly ash (Table 5), similar to a previous report [16]. They are stabilized within the glassy phase and crystal lattice structure of ceramsite and might be released into the environment [17]. It is therefore important to evaluate the heavy metal leaching and toxicity of ceramsite manufactured from CGCC and to assess its potential risk to human health [17]. The concentrations of trace elements leaching from various ceramsites were illustrated in Fig. 3 and Table 6. The leaching chromium $(\mathrm{Cr})$ was negatively correlated with the sintering temperature $(p$-value $=0.014$; Fig. $3 a)$, whereas arsenic (As) was the opposite (p-value $=0.037$; Fig. $3 b$ ). High temperature $\left(>1,000^{\circ} \mathrm{C}\right)$ benefited the formation of crystalline structure in ceramsite, significantly improved the interaction between heavy metal cations and negatively charged clay particles, and ineluctably enhance their stability [9-10]. The leaching mercury ( $\mathrm{Hg})$ had a negative relationship with CGCC content (Fig. 3c), explained by the reduction and improved evaporation by the organic matters in clay. Due to the homogeneous oxidation of combustion, the dominant $\mathrm{Hg}$ speciation in CGCC or fly a)

Pearson correlation coefficient $=-0.686$ $\mathrm{p}$-value $=0.014$

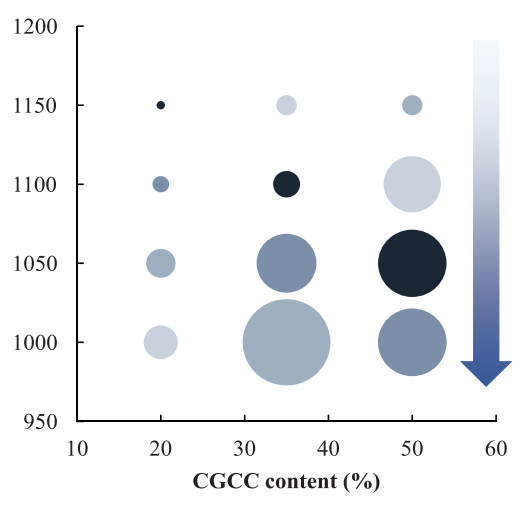

Sintering time (min) $\bullet 10 \quad 30 \quad \bullet 0 \quad \bullet 90$ b) Pearson correlation coefficient $=0.606$ p-value $=0.037$

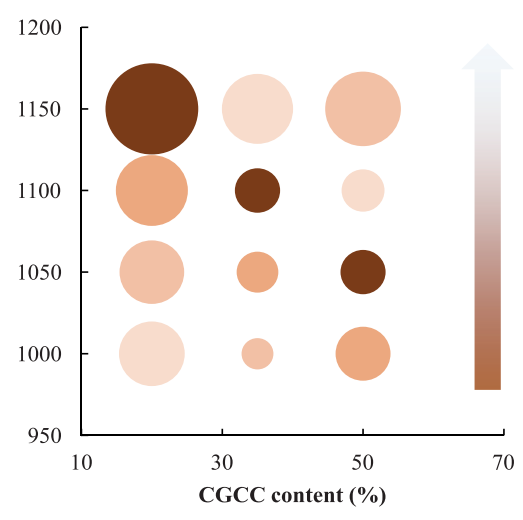

Sintering time (min) $\quad 10 \quad 30 \quad 60 \quad \bullet 90$ c) Pearson correlation coefficient $=-0.765$ $\mathrm{p}$-value $=0.004$

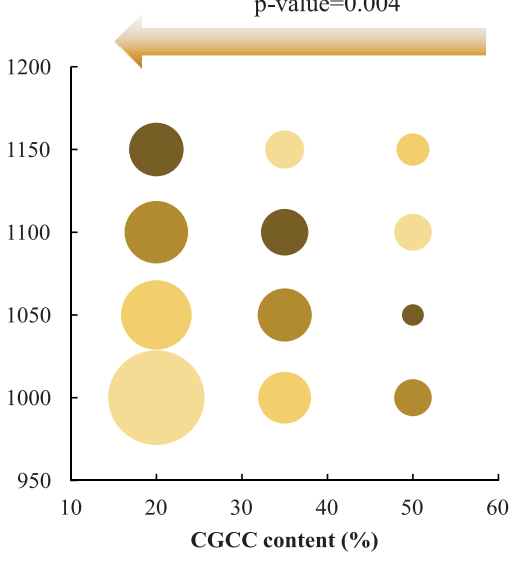

Sintering time (min) $\quad 10 \quad \bullet 30 \quad 60 \quad \bullet 90$

Fig. 3. The leaching toxicity of ceramsite as $\mathrm{Cr}$ a), $\mathrm{As} \mathrm{b}$ ), and $\mathrm{Hg}$ c). The diameter of the air bubble is positively correlated with the concentrations of trace elements $(\mathrm{Cr}, \mathrm{As}$, and $\mathrm{Hg})$, and the various shades represent different sintering times. 
Table 6. The leaching trace elements of ceramsite $(\mu \mathrm{g} / \mathrm{L})$ under different manufacturing conditions.

\begin{tabular}{|c|c|c|c|c|c|c|}
\hline \multicolumn{2}{|c|}{ Samples } & Cr & As & Hg & Results \\
\hline CGCC content $(\%)$ & Temperature $\left({ }^{\circ} \mathrm{C}\right)$ & Time $(\min )$ & $<15000$ & $<5000$ & $<100$ & - \\
\hline 20 & 1,000 & 10 & 622.1 & 55.4 & 2.16 & Qualified \\
\hline 20 & 1,050 & 30 & 461.1 & 53.5 & 1.16 & Qualified \\
\hline 20 & 1,100 & 60 & 147.2 & 66.4 & 0.94 & Qualified \\
\hline 20 & 1,150 & 90 & 38.6 & 110.5 & 0.69 & Qualified \\
\hline 35 & 1,000 & 30 & $4,106.0$ & 13.0 & 0.65 & Qualified \\
\hline 35 & 1,050 & 60 & $1,908.0$ & 22.3 & 0.68 & Qualified \\
\hline 35 & 1,100 & 90 & 387.1 & 26.2 & 0.53 & Qualified \\
\hline 35 & 1,150 & 10 & 224.7 & 64.9 & 0.35 & Qualified \\
\hline 50 & 1,000 & 60 & $2,524.0$ & 38.8 & 0.33 & Qualified \\
\hline 50 & 1,050 & 90 & $2,503.0$ & 26.1 & 0.11 & Qualified \\
\hline 50 & 1,100 & 10 & $1,746.0$ & 23.7 & 0.33 & Qualified \\
\hline 50 & 1,150 & 30 & 221.6 & 73.7 & 0.25 & Qualified \\
\hline
\end{tabular}

ash is $\mathrm{Hg}^{2+}$ [18]. The clay is rich in organic matters, which possibly act as reducers to convert $\mathrm{Hg}^{2+}$ to $\mathrm{Hg}^{0}$ [19-20], consequently causing more $\mathrm{Hg}$ evaporation during the sintering process and the lower $\mathrm{Hg}$ residual in ceramsite with high CGCC content. Similar to physical properties, there was no significant effect of sintering time on ceramsite leaching toxicity. All the leaching heavy metals (Table 6) matched the identification Standard for Leaching Toxicity from Hazardous Waste in China (GB5085.3-2007), showing the feasibility and minimal ecological impacts to recycle CGCC by ceramsite manufacturing.

\section{Conclusions}

Of the three parameters, CGCC content and sintering temperature play key roles in both physical properties and leaching toxicity of ceramsite, whereas the impact of sintering time is minimal. Though high concentrations of heavy elements $(\mathrm{Cr}, \mathrm{As}$, and $\mathrm{Hg}$ ) were found in raw $\mathrm{CGCC}$ material, the sintering manufacturing process effectively improved the thermodynamic stability of heavy metals by crystalline structure formations at high temperatures, showing limited human health risk. Considering the energy conservation and the maximal recycling of CGCC, optimal ceramsite manufacturing is suggested as $50 \%$ CGCC content, $1,150^{\circ} \mathrm{C}$ sintering temperature, and 10 min. sintering time. Our study proved the concept of CGCC being sustainable and environmentally friendly recycling. Manufactured into ceramsite, the CGCC wastes from the coal gasification industry are successfully reutilized for civil and construction purposes. Finally, the local authorities and the coal gasification plants should give more financial support for the recycling of CGCC, which is important for promoting the development of manufacturing ceramsite from CGCC waste.

\section{Acknowledgements}

The authors would like to thank the National Basic Research Program of China (973 Program, No. 2014CB238906) for financial support.

\section{References}

1. LI P., YU Q.B., QIN Q., LIU J.X. Adaptability of Coal Gasification in Molten Blast Furnace Slag on Coal Samples and Granularities. Energy Fuels. 25, 5678, 2011.

2. DELLANTONIO A., FITZ W.J., CUSTOVIC H., REPMANN F., SCHNEIDER B.U., GRUNEWALD H., GRUBER V., ZGORELEC Z., ZEREM N., CARTER C., MARKOVIC M., PUSCHENREITER M., WENZEL W.W. Environmental risks of farmed and barren alkaline coal ash landfills in Tuzla, Bosnia and Herzegovina. Environ Pollut. 153, 677, 2008.

3. LI Y., LI J.H., CHEN S.S., DIAO W.H. Establishing indices for groundwater contamination risk assessment in the vicinity of hazardous waste landfills in China. Environ Pollut. 165, 77, 2012.

4. VERMA S.K., MASTO R.E., GAUTAM S., CHOUDHURY D.P., RAM L.C., MAITI S.K., MAITY S. Investigations on PAHs and trace elements in coal and its combustion residues from a power plant. Fuel. 162, 138, 2015.

5. JIA J.L., LI H.B., ZONG S., JIANG B., LI G.H., EJENAVI O., ZHU J.R., ZHANG D.Y. Magnet bioreporter device for ecological toxicity assessment on heavy metal contamination of coal cinder sites. Sens Actuators, B. 222, 290, 2016.

6. JIA J.L., WU Y., YANG L., WU P.J., LI X.J., SUN X.T. Human health risk assessment of harmful trace elements in coal gasification residues. J Residuals Sci Tech. 12, S97, 2015.

7. CRUZ N.F.D., FERREIRA S., CABRAL M., SIMÕES P., RUI C.M. Packaging waste recycling in Europe: Is the industry paying for it? Waste Management. 34, 298, 2014. 
8. QIN J, CUI C, CUI X.Y., HUSSAIN A, YANG C.M. Preparation and characterization of ceramsite from lime mud and coal fly ash. Constr Build Mater. 95, 10, 2015.

9. WANG C., ZHANG F.S. Zeolite loaded ceramsite developed from construction and demolition waste. Mater Lett. 93, 380, 2013.

10. LIU J.Z., LIU R., HE Z.M., BA M.F., LI Y.S. Preparation and microstructure of green ceramsite made from sewage sludge. J Wuhan Univ Technol. 27, 149, 2012.

11. QIN J., CUI C., CUI X., HUSSAIN A., YANG C.M., YANG S.H. Recycling oflimemudand fly ash for fabrication of anorthite ceramic at low sintering temperature. Ceram Int. 41, 5648, 2015.

12. IBARRA J.V., MUNOZ E., MOLINER R. FTIR study of the evolution of lignite structure during the ligniteification process. Org Geochem. 24, 725, 1996.

13. DINGEMANS G., VAN HELVOIRT C.A.A., PIERREUX D., KEUNING W., KESSELS W.M.M. Plasma-assisted ALD for the conformal deposition of $\mathrm{SiO}_{2}$ : process, material and electronic properties. J Electrochem Soc. 159, H277, 2012.
14. LI W.L., TIAN S.B., ZHU F. Sulfonic acid functionalized nano- $\gamma-\mathrm{Al}_{2} \mathrm{O}_{3}$ : a new, efficient, and reusable catalyst for synthesis of 3-substituted-2H-1, 4-benzothiazines. Sci World J. 7, 1, 2013.

15. XU G.R., ZOU J.L., LI G.B. Effect of sintering temperature on the characteristics of sludge ceramsite. J Hazard Mater. 150, 394, 2008.

16. AHMARUZZAMAN M. A review on the utilization of fly ash. Prog Energy Combust Sci. 36, 327, 2010.

17. XU G.R., ZOU J.L., LI G.B. Stabilization of heavy metals in sludge ceramsite. Water Res. 44, 2930, 2010.

18. WILCOX J., RUPP E., YING S.C., LIM D.H., NEGREIRA A.S., KIRCHOFER A., FENG F., LEE K. Mercury adsorption and oxidation in coal combustion and gasification processes. Int J Coal Geol. 90, 4, 2012.

19. RAVICHANDRAN M. Interactions between mercury and dissolved organic matter - a review. Chemosphere. 55, 319, 2004.

20. XU J.Y., KLEJA D.B., BIESTER H., LAGERKVIST A., KUMPIENE J. Influence of particle size distribution, organic carbon, $\mathrm{pH}$ and chlorides on washing of mercury contaminated soil. Chemosphere. 109, 99, 2014. 
